\title{
Some medical syndromes encountered in nineteenth-century French literature
}

Margaret M Platts Retired Physician, Sheffield

\begin{abstract}
The medical content of a hundred selected French novels written between 1815 and 1914 has been examined. These books reflect contemporary public interest in medicine and disease. By means of translated quotations, the spectrum of diseases common at the time, including conditions nowadays rarely or never observed, such as smallpox and diphtheria, are graphically described, along with the effects of treatment of syphilis with mercury and the ravages of tuberculosis including lupus vulgaris. Some diseases which were not understood in the nineteenth century such as cretinism due to iodine deficiency may be recognised by the modern reader while other illnesses, convincingly described, are now unidentifiable. In the novels one can trace the transition from the humoral theory of disease to modern diagnoses and the advent of surgery and its complications. These extracts complement textbooks of the history of medicine by third-party depiction of the observed impact of disease upon the individual.

(F Med Ethics: Medical Humanities 2001;27:82-88)
\end{abstract}

Keywords: Disease; nineteenth-century French novel

\section{Introduction}

In the nineteenth century, France was the acknowledged leader in medicine and simultaneously there was an extraordinary flowering of French novels written by such realist and naturalist authors as Balzac, the Goncourts, Zola and Flaubert. They evinced considerable interest in medical topics and strived to ensure the accuracy of their observations by reading medical texts, by visits to hospitals and, of course, from their personal observations of illness. Some, such as Sue and Léon Daudet, had had medical training while Flaubert's father and brother were doctors. They described many medical syndromes in personalised and dramatic prose which is more luminous than that of the modern medical textbook. Because of the change in the incidence of different diseases over the past one to two hundred years wrought by immunisation, antibiotics and the greater longevity of man, some of the illnesses vividly depicted such as smallpox, syphilis and diphtheria have now partially or entirely disappeared from the Western world. Some complaints, however, apparently described from life, are unrecognisable to the modern physician and yet others are familiar to us although the syndromes had not been delineated and named by the doctors of the period of the novel.
The purpose of this paper is to detail some of these phenomena, supported by my translations of quotations from the novels, to comment on their social and literary context, and to attempt to explain them. Copies of the quotations in the original French may be obtained from the author by e-mail.

About a hundred French novels which contain medical subject matter and which were first published between the cataclysmic events of the end of the French Revolution in 1815 and the beginning of the first world war in 1914 were studied as material for a thesis on the medical aspects of the literature of this period. Some of this work is presented in this paper.

Although pioneers such as Bichat (1771-1802) began the century-long task of identifying diseases by correlation of clinical illnesses with postmortem examination findings, this knowledge was slow to filter down to authors of novels and the lay public in general. The productive periods of the two literary giants, Honoré de Balzac (1799-1850) and Emile Zola (1840-1902) were separated by a change in medical thinking catalysed by the publication in 1865 of Claude Bernard's Introduction à la Médecine Expérimentale, a book which greatly influenced Zola, who believed he could depict the actions of his characters as the results of external conditions. ${ }^{1}$ The identification in the last third of the century of most of the pathogenic bacteria and the development of anaesthesia and aseptic and antiseptic techniques, which allowed rapid advances in surgery, also distinguished this period from the early years of the century.

\section{Observations}

The novels of the first half of the century reveal few illnesses recognisable today and the behaviour of the doctors shows that many maladies were ill defined diagnostically. Thus Balzac retained some belief in elements of the humoral basis of medicine which had persisted since the time of Hippocrates, and remarks in Le Cousin Pons (1847):

"Patients in whom the liver is attacked to a greater or lesser extent are inclined to impatience and anger... . It is a kind of fever which shakes man's humoral mechanism because this fever is neither in the blood nor in the brain."

Yet, later, the book reveals that the patient is suffering from gall stones, a very concrete cause of jaundice, and treatment by operation is discussed. 
With the fading of belief in the humoral basis of disease and before the discovery of bacteria, the aetiological vacuum was filled by belief in the dangers of changes in the weather, profound emotions and, particularly in the case of Zola, heredity. This belief in the dangers of deep emotion is epitomised by a syndrome from which several fictional women suffered. For instance Constant describes the development of this illness in the heroine of Adolphe (1826) after she has received a letter of rejection from, her lover:

"She threw herself on her bed without saying a word. One of her women, worried by the shaking which she had seen had stayed, unnoticed, in her room ... towards the middle of the night this woman had seen her seized by a trembling which shook the bed ... she had passed the night uttering broken, incomprehensible words ... Ellénore [the patient] had fallen into a deep sleep. He, [the doctor], did not despair of saving her if, when she woke up, the fever was reduced." 3

Adéline in La Cousine Bette (Balzac, 1846) suffers from the same complaint when she is deserted by her husband:

"Adeline dashed into her room trembling more than ever; her children, frightened, followed her there on hearing a piercing scream. The unconscious baroness was picked up, it was necessary to put her to bed because she had developed a nervous fever which kept her between life and death for a month."

The mention of fever does not necessarily indicate that the body temperature was raised. The use of the clinical thermometer did not become general until the end of the century and the diagnosis of fever was usually based on a patient's flushed appearance and rapid pulse.

The fact that several authors give virtually identical descriptions of a dramatic illness in young women who have received an emotional shock suggests that such attacks did actually occur; but the syndrome disappears from the literature after about 1870 . The obvious diagnosis is a form of hysteria, and sure enough, in the forty-volume Nouveau Dictionnaire de Médecine et Chirurgie (1874), there is a long article which describes the many manifestations of the syndrome which begins with a "hysterical cry" followed by loss of consciousness and fits which are virtually indistinguishable from epilepsy. ${ }^{5}$ Then follows a very deep coma during which the patient may appear to be dead. In some patients the symptoms may continue for several weeks. The doctor in Balzac's Ursule Mirouët (1841) maintains that this illness may be fatal. ${ }^{6}$

Whatever its fundamental nature this syndrome is not seen today. A modern woman deserted by her lover is not encouraged to dramatise the event but is expected to distract herself with work or to find another partener. Rothfield, ${ }^{7}$ states that in the nineteenth century hysteria in women and epilepsy in men were the same disease, and Nancy Rogers ${ }^{8}$ discusses this syndrome in full and furnishes further examples.

Another mysterious condition is described by Balzac in La Cousine Bette (1846). It is an acute venereal disease acquired by a woman from a Brazilian lover and transferred by her to her husband. They both become mortally ill and the doctor says of the woman:

"The poor woman, who was said to have been pretty, is well punished for her sin because she is today revoltingly ugly, if she is still anything at all! Her teeth and her hair are falling out, she looks like a leper, she horrifies herself, her hands are swollen and covered in greenish pustules; her loosened nails remain in the wounds which she scratches, finally all her extremities are being destroyed by the decomposition which is eating them away."

The family physician, Dr Bianchon, who is the epitome of the good physician in many of Balzac's novels, summons seven colleagues in consultation but their discordant remarks highlight the lack of diagnostic precision of the day. Here the doctors discuss the case:

"Two serious opinions divided these princes of science. One, alone in his opinion, held that it was a poisoning, talked of an act of personal vengeance and did not think that he had rediscovered an illness described in the Middle Ages. Three others thought they were seeing a decomposition of lymph and humours. The second group, that of Bianchon, maintained that this illness was caused by a contamination of the blood which was corrupted by an unknown morbid principle." 10

Bonnet-Roy, ${ }^{11}$ has suggested that this disease was yaws but the clinical description is atypical and more resembles the state of patients with syphilis poisoned by their mercurial drugs. (See later quotations.)

In general Balzac mentions few definitive diagnoses and many of his characters die without any cause being suggested but in contrast, later in the century, many well known conditions are described with which the writer, the reading public and contemporary physicians would be far more familiar than we are now.

A common, fatal disease of the epoch was croup, often due to diphtheria, here described in L'Education Sentimentale by Flaubert (1869) :

"The child started to pull the clothes from his neck as if he wished to remove the obstacle which was suffocating him; and he scratched the wall, grabbed hold of the curtains of his little bed, seeking a support in order to breathe. His face was bluish now and all his body, soaked by a cold sweat seemed to become thinner... . But he shuddered throughout the entire length of his body like a wave blown by the wind, his eyeballs protruded... in the end he vomited something strange which resembled a tube of parchment. What was it? She [his mother] imagined that he had brought up part of his gut. But he was breathing deeply, regularly." ${ }^{12}$ 
Flaubert went to observe a child in this condition but he had not the stomach to watch the proposed tracheostomy hence, in the novel, the child is relieved by spontaneous ejection of the false membrane. Flaubert (1856) also meticulously describes the details of Madame Bovary's death from acute arsenic poisoning. ${ }^{13}$

The courtesan, Nana, (Zola, 1880) dies of confluent smallpox in a hotel bedroom:

“... [she] was a charnel-house, a pile of fluid and blood, a shovelful of rotting flesh thrown there onto a cushion. The pustules had invaded her entire face, one spot touching the other, only faded and sunken, with the appearance of greyish mud, they already resembled an earthy mould on this formless pulp where features were no longer discernible. One eye, the left one, had completely disappeared into the fermenting purulence, the other, half open, was sunken like a black, decaying hole. The nose was still suppurating. A large red crust extended from one cheek to invade the mouth which it pulled into an abominable grin. And, on the horrible, grotesque mask of nothingness the hair, the beautiful hair, keeping its sunny flame ran in a stream of gold. Venus was decomposing." 14

This description is not inserted solely to make the reader's flesh creep. It has a deeper significance. Nana's lifestyle had put her at considerable risk of acquiring venereal disease so throughout the novel one waits for signs of syphilis (la grande vérole) to develop; but instead, at the end, she dies of smallpox (la petite vérole). Authors were still reticent about syphilis, of which their predominantly female clientele was supposed to be ignorant. It is probable that Zola selected smallpox as the cause of death of Nana as a kind of allegory of syphilis. There certainly would have been no clinical confusion between these two common diseases in the minds of doctors or the general public of the time. No mention of vaccination, which had been practised in France since the revolution, is made in connection with this episode.

Alcoholism was extremely common in nineteenth-century France and L'Assommoir (double meaning-the cudgel and the grog shop, Zola, 1877) paints a vivid picture of a patient with delirium tremens unmodified by modern sedative drugs:

"The cell was padded from top to bottom; on the floor there were two mats, one on top of the other and in a corner, a mattress and a bolster were laid out, nothing else. Inside Coupeau was dancing and shouting. A real scarecrow with his shirt in rags and his limbs thrashing about in the air; but a scarecrow which was not funny, oh no, a scarecrow whose racket made the hair all over one's body stand on end. An intern, a great blond and pink lad in a white apron, quietly seated, was taking notes. The case was curious, the intern did not leave the patient." ${ }^{15}$

This text closely follows the words of Magnan's Etude Expérimentale et Clinique sur L'alcoolisme (1874). ${ }^{16}$ The whole of Zola's book is based on the effects of alcoholism on the family and society, producing not only physical illness but also poverty, social degradation, violence and accidents as well as possible congenital defects in children conceived while their parents are drunk. ${ }^{17}$

Throughout the century the greatest killer was tuberculosis and beautiful heroines dying of pulmonary tuberculosis abound in the literature of the period, typified by the bohemian Mimi and the heroine of La Dame aux Camélias (1852). ${ }^{18} \mathrm{~A}$ near terminal haemoptysis often furnished a focal point of the story. There are also numerous references to scrofula or tuberculous adenitis and "carie des os", usually tuberculous disease of the bones and joints but the aetiology of these diseases was not appreciated until after Koch's discovery of the tubercle bacillus in 1882. A lurid account of lupus vulgaris, a tuberculous infection of the skin which is never seen in modern times, occurs in L'Evangéliste (1880) where a man who always wears a scarf over his face eventually commits suicide after which his hideous disfigurement is revealed. ${ }^{19} \mathrm{~A}$ woman, similarly veiled, is portrayed in Lourdes (Zola, 1894). One day her scarf slips and uncovers:

“. . . a lupus which had invaded her nose and the mouth, growing there little by little, a slow ulceration spreading ceaselessly under scabs, devouring the mucous membranes. The elongated head, like the muzzle of a dog with its rough hair and large round eyes, had become hideous. Now the cartilages of the nose were nearly eaten away, the mouth was retracted, pulled to the left by the swelling of the upper lip like an oblique slit, filthy and shapeless. A sweat of blood mixed with pus ran from the enormous livid wound."20

Other patients at Lourdes are so disfigured that they dine apart at a table reserved for "Les Monstres" a group which includes lepers and patients with cancers of the head and neck. $(1906) .^{21}$

The other great scourge of the era was of course syphilis itself, for which the almost universal treatment throughout the century was mercury administered either as an ointment or, later, as pills or injections. Therapy was considered adequate only when excessive salivation occurred and frequently caused loss of teeth and hair. Gruesome facial ulcerations described in novels as features of syphilis were, in fact, probably the results of secondary infections and necrosis spreading from gingival ulceration caused by mercury. A complete and detailed account of references to syphilis in French literature is given by Cabanès. ${ }^{22}$

General paralysis of the insane is also well described in the rapidly progressive dementia of the middle-aged, cultivated and educated Charles Demailly (1868) and Edmond Goncourt's diary gives an account of his brother's terrible death from the same condition. ${ }^{23}$ At that time the syphilitic aetiology of this disease, which also killed Baudelaire, was unknown.

Because of the public's dread of the disease and its sexual connotations, syphilis lends itself to 
exploitation in novels. In Le Lit 29 (1884) and in La Vengeance d'une femme (1874) the heroines consider that they are wreaking legitimate vengeance by transmitting their disease, the first to Prussian soldiers and the second to her husband who has killed her lover. ${ }^{24}$ The old woman who personifies syphilis in des Esseintes' dream in A Rebours (1884):

"was emaciated with dirty yellow hair, the face of a bulldog, russet coloured spots on her cheeks, teeth crooked and pushed forwards under a snub nose..

- This mysterious, sexless face was green and opened its violet eyelids to reveal terrible, cold, clear blue eyes; spots surrounded her mouth. $\mathrm{He}$ had before his eyes the picture of Syphilis." ${ }^{25}$

Among several publications which appeared around 1900 and which attempted to publicise the dangers of syphilis in society was Brieux' powerful play Les Avariés (1901), which was based on accurate information and case studies provided by the great syphilologist, Fournier. It was directed at women and "jeunes filles" as well as men and, although it is absolutely explicit in its information, it carefully avoids words or actions which could give offence. It explains virtually everything known about the course, transmission and treatment of syphilis at the time through the story of a young man suffering the early stages of the disease. He is engaged to be married and the doctor promises that, if the patient adheres to his course of mercurial treatment for three years, he will be cured. He will then be able to marry and his wife will bear healthy children. However, the young man is unwilling to follow this advice and the doctor continues:

"Ah well. You will have to know everything. You shall know what sort of disease that your wife will have five per cent of contracting without so much as having her leave asked. I have seen an unfortunate young woman, changed by this disease into the likeness of a beast. Her face, or I should rather say what remains of it, nothing but a flat surface seamed with scars... . Of the upper lip which had been completely eaten away not a trace remained..."26

Brieux also points out that the syphilitic infant with its ulcerated mouth may spread infection to its wetnurse who may then transmit it to her husband and her future children. Births of infants with congenital syphilis are described in this play and also in Sous-Offs (1890) and in Le Mal Nécessaire (1899). ${ }^{27}$

The French government attempted to stem the epidemic of syphilis, which was said to affect one in seven men, by the compulsory medical examination of prostitutes. In Chair Molle (1885) Lucie who works in a maison close is found to have signs of secondary disease and is carried off, kicking and screaming, for obligatory hospitalisation :

"Immediately this idea of hospital terrified her. In it she saw simultaneously a prison and a place of shame and torture. 'Oh! madame I beg you to keep me. After all it is here that I have caught this, in your service, to earn money for you'. The male nurses had grabbed her and held her in their strong hands. Lucie, savage, raged, spitting at Donard, who shrugged his shoulders at the end of the corridor." ${ }^{28}$

The redoubtable Nana once jumped out of a window to avoid a similar embarrassment.

Although there was reticence about syphilis in published literature which would be read by women, men corresponding with one another were outspoken and Flaubert writing to a friend says:

"In Beirut I collected V11 chancres! which have finished by joining up into two and then one ... each evening and morning I dress my unhappy dick. At last it is healed, in two or three days the scar will be closed." 29

Although this does not sound like syphilis he was treated with mercury, perhaps for a subsequent syphilitic infection, and suffered from excessive salivation and loss of hair and teeth.

In novels of the earlier part of the century syphilis only appears as veiled references but these are obvious once one is aware of their existence, as in Le Père Goriot (Balzac, 1834):

"Father Goriot was an old libertine whose eyes had only been saved from the malign influence of the remedies which his illnesses made necessary by the skill of his doctor. The disgusting colour of his hair resulted from this excess of drugs . . ." ${ }^{30}$

A different group of diseases is identified by us from the authors' meticulous descriptions although the contemporary interpretation of these illnesses is completely different from ours.

In Le Médecin de Campagne(1833) one of the inhabitants of an isolated, inland, mountain village is described thus:

“... a human face never illuminated by thought, a ghastly pale face where suffering seemed innocent and silent, like the face of a child which does not yet know how to talk.... The appearance of the forehead where the skin formed a large round fold, two eyes like those of a cooked fish, with a head covered with little, stunted, malnourished hairs, a head totally depressed and lacking all sensitive organs." ${ }^{31}$

It is interesting to note that the patient is known as a cretin but at that time this simply meant idiot. In the village, where goitre is also common, the doctor believes the condition is hereditary and sends many of the victims to live elsewhere while he rehouses all the other inhabitants and introduces reforms which greatly improve their diet and eliminate this disease. We, however, recognise the typical picture of endemic goitre and cretinism due to lack of dietary iodine in an inland, mountainous area.

The Goncourt brothers unwittingly give an excellent account of anorexia nervosa in their novel Soeur Philomène (1861). The adolescent Philomène, unhappy in her convent, stops eating:

" ... but the solicitude of the sisters was awakened since the deaths, not yet forgotten, of two or three girls who were attacked by a languor similar to 
Philomène's. They noticed that Philomène ate absolutely nothing in the refectory; they even surprised her hiding the bread she was given in the sleeves of her gown. The doctor of the house, who was called immediately, declared, after having visited Philomène, that her stomach was beginning to be disorganised."

The girl recovers when she is sent home from the convent.

The omission of certain diseases from the literature is interesting. Cardiac disease is mentioned relatively rarely though late in the century there is a good description of a coronary thrombosis in the hero of Dr Pascal (1893) and a doctor who listens with his ear directly on the chest of his colleague declares:

" . . the impulse is strong, the first sound is dull while the second, on the contrary, is very loud. The apex is displaced downwards and towards the axilla.... There is some sclerosis." ${ }^{33}$

"Hypertrophy" is mentioned as a cardiac diagnosis in Une Vie, (1883). ${ }^{34}$ Hypertension as a cause of hypertrophy was unknown as the sphygmomanometer had not been invented, while diagnosis of valvular disease by auscultation was a rare skill. Laënnec's construction of the stethoscope and his remarkable book (1819), in which most of the auscultatory signs which we recognise today are described, had evidently not influenced most practitioners before the end of the century. Most auscultation was done with the ear directly applied to the chest with a shirt or handkerchief intervening for hygienic reasons, as described in fack by Alphonse Daudet, ${ }^{35}$ (circa 1875) and in Les Morticoles by his son Léon Daudet (1894). ${ }^{36}$ It would be difficult to interpret anything heard under these conditions. The main use of the stethoscope at this time was as an aid to modesty in examining females to whom direct auscultation was unacceptable.

Throughout the century the commonest diseases were acute infections. In spite of the fact that hundreds of children died in France each year from measles and whooping cough there is almost nothing in the books about the fevers of childhood except croup. Several severe epidemics of cholera occurred, each of which killed thousands of people and one of these is described in Sue's Le Fuif Errant (1844-45). ${ }^{37}$ In this as well as in JK Huysman's Sac au dos (1890), ${ }^{38}$ which relates the trials of a soldier with dysentery, there is no mention of diarrhoea, a reticence which is odd in view of the freedom with which Zola discusses menstruation, even becoming lyrical when a chronically ill girl is cured at Lourdes and immediately has her first period:

"And Beauclair [a doctor], had added that Marie was a woman at last, that her maternal blood would burst forth in a peal of hosannas." 39

The outspoken Zola had also a great deal to say about obstetrics and gynaecology. In La foie de vivre (1884) he gives a detailed account of the delivery of a live infant which had presented transversely. An internal version is performed after spontaneous rupture of the membranes and all this, of course, in the patient's home and without anaesthesia. ${ }^{40}$ In Fécondité (1899) Zola pleads for large families and against horrific methods of contraception used at the time, notably hysterectomy or ovariectomy. These proceedures are also castigated in Le Docteur Mort-aux-Gosses (1894) and Les Femmes Eunuques (1899). ${ }^{41}$ Surgery was still risky because anaesthesia was limited to chloroform, surgeons were often inexperienced and of course there were no antibiotics so that abdominal operations complicated by sepsis were almost invariably fatal. Nevertheless one admires the dexterity of the hardpressed army surgeon in Le Débâcle (1892) who, during the Franco-Prussian war (1870), operates in an improvised field hospital with unsterilised instruments. ${ }^{42}$ Here abdominal injuries are always fatal while compound fractures nearly always necessitate amputation, with resultant sepsis and a very high mortality. Tetanus was common after both civilian and army injuries because of the presence of the spores of this disease in the faeces of the ubiquitous horse. But by the 1890s antiseptic and aseptic techniques had been adopted and in Les Femmes Eunuques (1899) the surgeon performs an ovariectomy clad in a bibbed apron and scrubs his hands in antiseptic; rubber gloves having not yet been invented. He boasts that every item of his equipment has been flamed and boiled in phenol for two hours. ${ }^{43}$

But the iconoclastic Léon Daudet, who had trained but not practised as a doctor, pillories surgeons in his novel Les Morticoles (1894). ${ }^{44}$ In this imaginary community virtually the whole population lives in a miasma of carbolic, but the surgeons operate before a lay audience and the patients are sent back to the wards with their wounds unsutured and with forceps still hanging onto bleeding points. There the unfortunate victims are tidied up by ribald medical students. Needless to say the sepsis and death rates are appalling. Daudet later assured readers that this and other atrocities depicted in this book were not exaggerated.

\section{Discussion and conclusions}

The passage of time and advances in medical knowledge are responsible for rendering old theories redundant and many nineteenth-century syndromes have all but disappeared from the corpus of common experience. It is thus that the medical content of the novels studied requires historical and literary research for its elucidation and has indeed revealed a remarkable pageant of descriptions of diseases which differ fundamentally from the diseases which are prevalent today.

The high infant and maternal mortality, the ubiquity of tuberculosis and syphilis and the prevalence of typhoid fever, lousiness and typhus were, at the beginning of the nineteenth century, part of the normal fabric of life, barely requiring comment and usually not recorded in official statistics. Similarly the alleged risks entailed by getting wet in the rain, the physical and moral dangers of bathing and the therapeutic efficacy of venesection were generally 
accepted as real. Now however, more than a hundred years later, when medical research has revealed the precise cause of many diseases, these beliefs seem ludicrous.

Several literary scholars have published studies of the the medical content of, usually, one author's work. Thus Bonnet-Roy, ${ }^{11}$ Moïse le Yeouanc ${ }^{45}$ and Winter ${ }^{46}$ have analysed the medical content of the works of Balzac while Rothfield ${ }^{7}$ has studied the medical background of Flaubert's Madame Bovary (1856). Others have attempted diagnosis of mysterious syndromes exhibited by some of the characters, for instance the blind beggar in Madame Bovary, ${ }^{47}$ who was in fact a concocted character synthesised by discussion between the author and a medical friend. One must accept that not all the invalids depicted in these works are drawn from life and may not suffer from specific illnesses but merely represent, as in the case of the beggar, an incarnation of sickness or evil.

The present work presents the medical content of some nineteenth-century French novels from a different angle, that of the interested physician, desirous of learning from this material something of the diseases of the period described, not academically in a medical text, but usually by direct observation.

Contemporary English novels do not seem to contain the same wealth of medical material. One remembers the description of typhoid in Charlotte Bronte's Fane Eyre $(1847)^{48}$ and several heroines fading gracefully away, presumably as a result of the ravages of tuberculosis. No purple medical prose here, just tear-jerking pathos. One can only speculate on the reason for this difference on the two sides of the Channel. Perhaps Victorian prudery precluded anything more direct in Britain or maybe the French public was more interested in medicine and its progress because many of the innovations were made in their own country. In any event they demonstrated an attitude akin to the modern public interest in medical, serialised, television "soaps". Many of the nineteenth-century novels were published as eagerly awaited weekly instalments in newspapers. As is usual in such publications it was customary to have a "cliffhanger" at the end of each episode and often this was furnished by the injury, suicide, or serious illness and threatened death of a character. Thus the authors used the medical material to provide focal points in the action or to introduce an element of drama or even a frisson of macabre or sexual interest into realist or naturalist novels. This perhaps goes some way to explain the rather odd absence of some common diseases such as cancer and the childhood fevers which had less dramatic or sexual appeal. In addition, descriptions of familiar diseases helped to imbue the works with verisimilitude

Little insights illuminate aspects of life and medicine which do not reach standard texts of the history of medicine. Thus the sight of "squadrons of rats" running in daylight down the dormitory of a bourgeois boarding-school $(1869)^{49}$ and the observation that pupils in a similar establishment washed their feet once a fortnight in the dining room, heighten one's appreciation of the ubiquity of poor hygiene. The commonness of chilblains testifies to the inadequacy of clothing and heating.

Very few of the novels are written in the first person and this work is specifically a study of novels rather than diaries or autobiographies. These works therefore rarely provide first-hand accounts of the effects of sickness on the individual. Nevertheless, it is obvious that most of the descriptions of disease are founded on either the personal observations of the author or on accounts given him by books or third parties. Since, in many instances these episodes of sickness, births and deaths are important and integral parts of the novels the behaviour of the characters is profoundly affected by them, illustrating an aspect of disease not usually addressed in treatises on medical history.

The tardy adoption of new techniques such as use of the stethoscope is perhaps not surprising when we remember the difficulty in learning to recognise the sounds heard through it in medical school. It must be even more daunting when self taught in middle life. To some extent one can follow the advances in medical knowledge through the century. The lingering belief in humours and the medical conferences around the rich patient's bed highlight the paucity of clear cut diagnoses available in the earlier part of the century. Later on one is regaled with descriptions of surgery often, in these books, performed for dubious reasons such as ovariectomy for contraception in young women. Other literature campaigned against various ills of the period such as alcoholism and syphilis.

Even allowing for a certain degree of "poetic" licence these novels remind and startle us by their revelation of the ubiquity of disability, deprivation and disease, and its poor prognosis in this period. Life was often short, painful and brutish. Finally we are reminded of the enormous advances in medicine which have occurred in the last hundred years and the horrors of treating, for instance, compound fractures or abdominal infections without antibiotics.

Curiously, many aspects of modern medicine seem simpler than those of the nineteenth century. With scientifically proven aetiologies and diagnosis of disease now usually readily confirmed in the living patient by imaging or bacteriological or blood test, prolonged diagnostic discussion and excessive precautions against such postulated precipitating factors as emotion and the weather have become less relevant. Medical textbooks are noticeably shorter and more precise and the corpus of medical knowledge is generally available to all doctors and "secret remedies" are illegal. One usually consults a single specialist in the expectation that similar advice would be proffered by any other doctor similarly qualified. But perhaps the overwhelming emotion aroused by reading these novels is thankfulness that we live in an age of antibiotics and plastic surgery so that the grossly disfiguring conditions described in the nineteenth century now rarely occur. 
But we must beware of complacency and smugness. What will people of the twenty-second century think of our fumbling attempts to prevent and cure cancer and of our poor understanding of such conditions as the chronic fatigue syndrome and the effects of stress?

\section{Acknowledgement}

The thesis from which the material for this paper is taken was written under the guidance of Professor David Walker of the Department of French, Sheffield University. I am very grateful to him for his kindness, advice and patience.

\section{Author's note}

Dates in the text after the titles of novels are those of first publication. Dates in the references are those of publication of the edition cited.

Margaret M Platts is a Retired Physician, living in Sheffield.Email: Margaret.Platts@care4free.net

\section{References and notes}

1 Bernard C. Introduction à la médecine expérimentale. Paris: Baillière et fils, 1865.

2 De Balzac H. Le cousin Pons. Paris: Bibliothèque de Pléiade, Gallimard, 1977: 669.

3 Constant B. Adolphe. Paris: G F Flammarion, 1989: 153-5.

4 De Balzac H. La cousine Bette. Paris: Livre de Poche 952, 1984 190 and 377 .

5 Nouveau dictionnaire de medécine et chirugie. Paris: Baillière et fils, 1874 .

6 De Balzac H. Ursule Mirouët. Paris: Folio Classique, Gallimard, 1981.

7 Rothfield L. Vital signs. Princeton: Princeton University Press, 1992: 38

8 Rogers N. The wasting away of the romantic heroine. Nineteenth-Century French Studies 1983;11:246-56.

9 See reference 4: 466

10 See reference 4: 468

11 Bonnet-Roy R. BALZAC les médecins, la médecine et la science. Paris: Horizons de France, 1944: 71

12 Flaubert G. L'éducation sentimentale. Paris: G M Flammarion, 1984: 350 .

13 Flaubert G. Madame Bovary. Paris: G M Flammarion, 1984.

14 Zola E. Nana. Paris: Collection Folio 956, Editions Gallimard, 1977: 474 .

15 Zola E. L'Assommoir. Paris: Livre de Poche 97, Fasquelle, 1979: 484-5.

16 Magnan. Etude éxperimentale et clinique sure l'alcoolisme. Paris: Académie de Medécine, 1874.

17 Furst LR. A medical reading of Gervaise in L'Assommoir. Symposium 1992; 46:195-207.
18 Dumas fils, A. La dame aux caméllias. Paris: Bookking International, 1994

19 Daudet A. L'évangeliste. Paris: E Flammarion, 1880.

20 Zola E. Lourdes. Paris: Bibliothèque Charpentier, 1894; 390.

21 Huysmanns J-K. Les foules de Lourdes. Paris: Librairie Plon, Plon et Nourrit, 1926.

22 Cabanès J-L. Invention(s) de la syphilis. Romantisme 1996;94: 89-109.

23 De Goncourt E, Goncourt J. Charles Demailly. Paris: Collection 10/18, 1990.

24 De Maupassant G. Le lit 29. In: Boule de suif. Paris: Livre de Poche 650, Albin Michel, 1984. Barbey d'Aurevilly J. La vengeance d'une femme. In: Les diaboliques. Paris: Libraire Alphonse Lemerre, 1874

25 Huysmans J-K. A Rebours. Paris: Collection Folio 898, Gallimard, 1977: 169-170.

26 Brieux E. Three plays by Brieux [translated by Shaw Mrs B, Hankin St J, Pollock J]. London: AC Fifield, 1911: 195.

27 Descaves L. In: Tresse, Stock, eds. Sous-offs [16th ed]. Paris: Collections Ressources, 1889-90. Couvreur A. Le mal nécessaire. Paris: Librairie Plon, Plon et Nourrit, 1899.

28 Adam P. In: Brancart A, ed. Chair molle. Brussels, 1885: 85-8.

29 Flaubert G. Letter to Louis Bouilhet 14/11/1850. Correspondence 1975;1:705.

30 De Balzac H. Le père Goriot. Paris: Folio 784, Gallimard, 1971 : 53.

31 De Balzac $\mathrm{H}$. Le médecin de campagne. Paris: Classiques Garnier, 1976: 21.

32 Goncourt E, Goncourt J. Soeur Philomène. Paris: Collection Guillaume, 1890: 63.

33 Zola E. Docteur Pascal. Oeuvres complètes 6. Paris: Cercle du Livre Précieux, 1967: 1145-1401.

34 De Maupassant G. A life (Une vie) [translated by Laurie $M$ and W]. London: Morrison and Gibb, 1949

35 Daudet A. fack. Paris: E Flammarion, c 1875

36 Daudet L. Les morticoles. Paris: Bibliothèque Charpentier, 1894.

37 Sue E. Le juif errant. Paris: Nouvelles éditions Oswald, 1978.

38 Huysman J-K. Sac au dos. In Soirées de Médan. Paris: Charpentier, 1880 .

39 See reference 20: 401

40 Zola E. La joie de vivre. Paris: Bibilothèque de la Pléiade, 1964.

41 Zola E. Fécondité. Oeuvres complètes 8. Paris: Cercle du Livre Précieux, Fasquelle, 1968. Dubut de Laforest J-L. Le docteur mort-aux-gosses. Paris: Fayard Frères, 1978. Dubarry A. In: Conchon F, ed. Les femmes eunuques. Paris, 1899.

42 Zola E. Le débâcle. Bibliothéque Charpentier, 1892.

43 See reference 41: Dubarry: 125-9.

44 See reference 36: 59-60.

45 Le Yeouanc M. Nosographie de l'humanité Balzacienne [thesis]. University of Paris, Lettres et Sciences Humaines, Librairie Maloine, 1959.

46 Winter MT. Valetudinarians and monomaniacs. Illness in selected works of La Comédie Humaine [PhD thesis]. New York Graduate Faculty in French: 1984

47 Donaldson-Edwards M. A pox on love: diagnosing Madame Bovary's blind beggar. Symposium 1990;46:15-27.

48 Bronte C. Fane Eyre. Harmondsworth: Penguin, 1994

49 Daudet A. Le petit chose. Paris: Fasquelle, 1947. 